\title{
The Effect of Organizational Culture and Job Satisfaction on the Work Productivity of Teacher at Vocational School No 1 in Bunga Mayang
}

\author{
Komariah $^{1 *)}$, Bukman Lian ${ }^{1}$, Alhadi Yan Putra ${ }^{1}$ \\ ${ }^{1}$ Universitas PGRI Palembang \\ *Corresponding author.E-mail: komariahzakaria@gmail.com
}

\begin{abstract}
Problems related to teacher work productivity at Vocational High School no 1 Bunga Mayang have not yet been achieved, because there has been no increase from the average KKM for the last 5 years and an increase in the percentage of graduation over the last 3 years. Based on the results of observations that the work productivity of Vocational High School no 1 Bunga Mayang has problems in job satisfaction from teachers, including there are still some teachers who are still honorary teachers and some who have become permanent teachers. For honorarium teachers, job satisfaction is still not sufficient. Job satisfaction is not only seen in terms of status, but it also can be seen in terms of work environment. The hypothesis in this study is that there is an influence of organizational culture on the work productivity of teachers of the 1 Bunga Mayang Vocational School. There is an effect of job satisfaction on the work productivity of teachers of Vocational School 1 Bunga Mayang. There is an influence of organizational culture and job satisfaction together on the work productivity of teachers of Vocational High School 1 Bunga Mayang.
\end{abstract}

Keywords: Organizational Culture, Job Satisfaction, Work Productivity

\section{INTRODUCTION}

School organizational culture is of concern to managers and observers of education, because school culture is seen as fundamental in the ability of schools to generate and maintain improvements in the quality or quality of schools. In addition, the development of a school culture will give birth to an organization's ability to succeed in making a change or responding to a change. School culture is a social interaction indicating that school culture includes elements of schedule, curriculum, demographics, and policies as social interactions that occur in these structures and show school views and feelings such as being friendly, elite and competitive. Raywid [1]

An organizational culture is a set of values, norms, perceptions, and behaviors that are created and developed by an organization / company to solve problems, both internal integration and external adaptation problems. The culture of an organization, as a unity of ideas, also serves as a guide for members in how to behave and act, or it contains a prohibition [2] to take an action in facing an environmental challenge. Work productivity does not just appear, but must be grown and stimulated through satisfaction. Job satisfaction is a feeling of attitude towards something experienced in connection with the work being done. [3]
Vocational High School no 1 in Bunga Mayang appears that in the implementation of their daily work is still necessary to have a leader who is able to provide direction and guidance to subordinates to enable teachers to have better productivity. [4] The figure of a leader who is able to provide encouragement and direction for teachers will greatly provide moral support and stability for employees in carrying out their daily work. So that with a leader who is able to provide a strong influence so that it will lead to organizational commitment to work more optimally.

On the other hand, organizational culture such as teacher professionalism and work cohesiveness still need to be improved, this can be seen in the work patterns of teachers who still show deficiencies in providing services to students. With a strong organizational culture, organizational commitment will emerge which will ultimately increase work productivity. Another factor that supports or creates good productivity is that efforts to provide satisfaction to teachers have not been able to be realized optimally. This condition is supported by the spirit of teachers who are still not enthusiastic in carrying out their work because sometimes it is not based on the abilities of the teacher, as well as the organizational climate that needs to be improved in order to provide work comfort. The conditions mentioned above need to be taken as soon as possible so that employee productivity is better. 
The work productivity of the Bunga Mayang 1 Vocational High School teachers has not shown maximum results, such as there are still jobs that are not completed as expected or errors often occur in carrying out tasks. If this situation is left unchecked, it is not impossible that the goal of Bunga Mayang Vocational High School 1 cannot be achieved properly and correctly. Therefore, the OKU Timur district Education Office continues to try to find the cause of the work productivity of these teachers is not optimal. Seeing the above, the researcher is interested in examining why the work productivity of teachers at Bunga Mayang Vocational High School no 1 is not in line with expectations, whether the current organizational culture is not supportive for teachers to work well or teachers do not get satisfaction at work. Culture in an organization may be able to affect the work productivity of teachers, where an uncomfortable work atmosphere will make teachers unable to work properly, or communication between teachers does not work well so that teachers work alone.

Achieving goals at Bunga Mayang Public Vocational High School 1 is inseparable from the existing management roles such as the existing organizational culture. Organizational culture needs to be improved and developed so that all individuals within the organization have a clear and firm work philosophy on how to carry out their duties. In addition, in an organization must have values that are understood and shared by all levels of the organization. Teachers must work seriously to formulate and apply organizational values so that the organization is successful in creating a strong organizational culture that can increase the morale of teachers in carrying out their daily tasks. If the organizational culture has been understood and obeyed by all teachers, it is expected that teachers can work better and have high performance so that they can do work optimally.

[5]In addition to creating a good organizational culture in the work environment, it is also possible to increase the work productivity of teachers at Bunga Mayang Vocational High School 1 is the job satisfaction of teachers for the results they achieve in the organization. Job satisfaction is very important for selfactualization. Teachers whose job satisfaction levels are low will never reach psychological maturity at work and in turn will become frustrated, this will have negative consequences for the teacher himself. Low morale, no motivation, lack of passion, the completion of his task is not optimal and will give birth to negative behavior. A person will feel satisfied with what he has done if the results of his work are what he wants.

[6] Based on some of the problems that have been mentioned, the job satisfaction achieved by the teacher is related to the culture of the organization or where the teacher works. This linkage is that when the teacher feels able to achieve job satisfaction, the teacher will continue to show a positive attitude towards his job. This is related to the prevailing culture in schools, namely the teacher will obey applicable school rules such as coming to school on time, teaching according to schedule, low absenteeism rates and so on. This will be different if the teacher is lacking or even unable to achieve job satisfaction as expected, then the teacher will show negative attitudes which have an impact on the weak organizational culture that is formed. This is because teachers tend to weaken organizational culture. For example, teachers often arrive late, teach not according to a predetermined schedule, often do not attend school and even violate various other school rules.

By paying attention to all that the authors have mentioned, the authors are interested in researching "The influence of organizational culture and job satisfaction on the Work Productivity of Teachers of Vocational High School 1 Bunga Mayang"

\section{LITERATURE REVIEW Work Productivity}

states that the productivity of an organization is influenced by many factors, such as the opportunity to obtain additional education and training, fair, rational and objective work performance appraisals, reward systems and various other factors. Anticipating a freer economic climate with the existence of the World Trade Organization (WTO), AFTA in 2003, and APEC in 2020, government and private institutions need to prepare the competitiveness of human resources to increase productivity. Productivity issues have been raised from the surface, ranging from propaganda in the form of slogans or banners to becoming a special topic of conversation in a seminar on a national scale.

Apart from being the ratio of output to input, there are experts who define productivity by looking at it from other dimensions. In terms of being efficient and effective. [7] suggests that productivity is how well the various resources we manage together and use them to achieve a specific level of results or goals. In other words, how to do something better and work smarter, not just harder.

Recently, thinking about productivity has emphasized the human aspect of the production system [8] The description of thoughts can be done through a coordination approach in forming a productive work culture with the principle of working together and working together based on the law in accordance with the prevailing cultural patterns.

From the above definitions, it can be synthesized that work productivity is the quality and quantity of output that is measured based on several predetermined standards with dimensions and indicators of work quality and work quantity of employees developed into indicators; Ability; Way of working; Skills; Speed at work; The results achieved; Error rate and work volume.

\section{Organizational culture \\ According to [8] Organizational culture is the norms and values that direct the behavior of}


organizational members. Each member will behave in accordance with the prevailing culture in order to be accepted by the environment. Changes in the external environment of the organization, among other changes in political, economic, social and the environment in a very tight competition. Changes in the internal situation of the organization include vision, mission, strategy, organizational structure, and technology. Organizations must know the parts of the organization that need to change in order to survive in a changing environment, like Weick who applied Darwin's theory of survival of the fittest to the organization [9] [10].

According to organizational culture is defined as a basic assumption that is found and developed by a certain group whose function is to solve problems originating from problems of external adaptation and internal integration. Meanwhile, in it defines organizational culture as a function of belief patterns, symbols, rituals, and myths as the glue in uniting an organization and always developing with time. Organizational culture is often described in terms of sharing.

According to [11] organizational culture is a value that is owned by an organization that is felt and understood by all members of the organization. This value is reflected in the beliefs, symbols, rituals, myths and practices that occur in the organization. These values serve as guidelines or instructions for organizational members to behave. A strong organizational culture can control the minds, souls and bodies of organizational members.

Meanwhile, according to [11] organizational culture is a value system that is held by organizational members to differentiate the organization from other organizations. Next, says that "Organizational culture refers to a shared system of meanings owned by members that distinguishes an organization from other organizations." Organizational culture is a system adopted by organizational members that differentiates one organization from another.

From the above theories it can be concluded that organizational culture is a concept that continues to develop and must be considered in an organization to succeed in creating a good culture in the world of education. It can be concluded that organizational culture is a pattern of beliefs and values of the organization are believed and instilled into all of its members to do the job as the right way to understand, to think, and feel about issues related to, so that will be a value or rules in the organization.

\section{Job Satisfaction}

According to Job satisfaction is a set of employee feelings about whether their job is fun or not. There is an important difference between this feeling and the other two elements of employee attitude. Job satisfaction generally refers to the attitude of an employee. Job satisfaction has many dimensions it can represent a holistic attitude and refers to a person's part of the job. The positive effects of feeling satisfied or happy include increased work motivation, increased love, loyalty, discipline and dedication to the job and institution where he works. On the other hand, the impact of feeling dissatisfied and unhappy with the results achieved in his work includes weak work motivation, reduced love, loyalty, dedication to the job and the institution where he works.

According to Maslow's theory (quoted by that the fulfillment of needs including the lowest level does not lead people to a feeling of satisfaction and leads to a neutral work attitude. This is due to the need for support from other people or from the community. The expression of pleasant or unpleasant emotional conditions is a picture of employee job satisfaction.

This is also stated by that job satisfaction is considered as a person's attitude towards the job itself. The theory states that each individual has different needs, including the need for self-actualization, motivators, achievements, affiliation and power. Job satisfaction is very much dominated by several models, namely fulfillment of needs, mismatch, work achievement value and attendance.

According to job satisfaction is a general positive attitude of a person towards his work life. Job satisfaction is strongly influenced by the ability of work institutions to create, foster, maintain and develop the quality of work life as a work environment conditions faced by workers.

Based on the descriptions of the theories above, it can be concluded that job satisfaction is a positive or happy feeling from someone towards their work which is oriented towards the results of their work so far. With dimensions 1 . the nature of the work itself, 2. work environment, pay and rewards, 3. work results achieved.

\section{METHODS}

The research was conducted at the Bunga Mayang 1 Vocational High School because it is actively implementing an increase in teacher work productivity in an effort to achieve institutional goals.

In this study the authors used quantitative data, namely research that is required to use numbers, starting from data collection, interpretation of the data, and the appearance of the results. Quantitative research is a type of research whose specifications are systematic, planned, and clearly structured from the start to the making of the research design.

The population that became the object of the study were all 45 teachers of the Vocational High School Negeri 1 Bunga Mayang. In this study the researchers took the entire population of 45 people as the research sample. Meanwhile, for testing the research instrument, the researcher will use another school in the vicinity of the Bunga Mayang 1 Vocational High School, namely the Private Vocational School of the Bakti Ibu Education Foundation (YPBI) as many as 20 teachers.

Data collection techniques are the most important step in research, because the main purpose of research is to get data. Without knowing the data collection 
technique, the researcher will not get data that meets the established data standards

\section{RESULTS AND DISCUSSION}

Hypothesis testing is done by using correlation techniques, while the correlation techniques used are statistical analysis of correlation and determination, regression coefficient ( $\mathrm{t}$ test) and association correlation coefficient (F test), which were carried out using SPSS version 21 .

1. Testing the Hypothesis of Organizational Culture (X1) on Teacher Productivity (Y) Tabel 1

Hasil Uji X1 Terhadap Y

\begin{tabular}{|c|c|c|c|c|c|c|}
\hline \multicolumn{7}{|c|}{ Coefficients $^{a}$} \\
\hline & & \multicolumn{2}{|c|}{$\begin{array}{l}\text { Unstandardized } \\
\text { Coefficients }\end{array}$} & \multirow{2}{*}{$\begin{array}{c}\begin{array}{c}\text { Standardized } \\
\text { Coefficients }\end{array} \\
\text { Beta } \\
\end{array}$} & \multirow[b]{2}{*}{$\mathrm{t}$} & \multirow[b]{2}{*}{ Sig. } \\
\hline \multicolumn{2}{|c|}{ Model } & $\mathrm{B}$ & Std. Error & & & \\
\hline \multirow[t]{2}{*}{1} & (Constant) & 6.105 & 5.551 & & 1.100 & .278 \\
\hline & $\begin{array}{l}\text { Budaya } \\
\text { Organisasi }\end{array}$ & .878 & .069 & .889 & 12.705 & .000 \\
\hline
\end{tabular}

From the table above, the $\mathrm{t}$ value is 12,705 with a sig level of 0,000 . Because the sig value is less than 0.05 , the hypothesis which says there is an influence of Organizational Culture on the work productivity of Vocational High School 1 Bunga Mayang teachers is accepted. This means that organizational culture has an effect on the work productivity of teachers in Vocational High School 1 Bunga Mayang.

2. Hypothesis Testing of Job Satisfaction (X2) on Work Productivity (Y).

Table 2

X2 Test Results Against Y

\begin{tabular}{|c|c|c|c|c|c|c|}
\hline \multicolumn{7}{|c|}{ Coefficients $^{a}$} \\
\hline & & \multicolumn{2}{|c|}{$\begin{array}{l}\text { Unstandardized } \\
\text { Coefficients }\end{array}$} & \multirow{2}{*}{\begin{tabular}{|c|}
$\begin{array}{c}\text { Standardized } \\
\text { Coefficients }\end{array}$ \\
Beta \\
\end{tabular}} & \multirow[b]{2}{*}{$\mathrm{t}$} & \multirow[b]{2}{*}{ Sig. } \\
\hline \multicolumn{2}{|c|}{ Model } & $\mathrm{B}$ & Std. Error & & & \\
\hline \multirow[t]{2}{*}{1} & (Constant) & 2.949 & 5.836 & & .505 & .616 \\
\hline & $\begin{array}{l}\text { Kepuasan } \\
\text { kerja }\end{array}$ & .849 & .074 & .870 & 11.545 & .000 \\
\hline
\end{tabular}

From the table above, the $\mathrm{t}$ value is 11,545 with a sig level of 0,000 . Because the sig value is less than 0.05 , the hypothesis which says there is an effect of Job Satisfaction on the work productivity of teachers of Vocational High School 1 Bunga Mayang is accepted. This means that Job Satisfaction affects the work productivity of teachers of Vocational high School 1 Bunga Mayang is accepted.

3. Testing the Hypothesis of Organizational Culture (X1) and Job Satisfaction (X2) on Work Productivity (Y)

Table 3

Test Results X1 and X2 Against Y

\begin{tabular}{|c|c|c|c|c|c|c|}
\hline \multicolumn{7}{|c|}{ ANOVA $^{\mathrm{a}}$} \\
\hline \multicolumn{2}{|c|}{ Model } & $\begin{array}{l}\text { Sum of } \\
\text { Squares }\end{array}$ & df & $\begin{array}{l}\text { Mean } \\
\text { Square }\end{array}$ & $\mathrm{F}$ & Sig. \\
\hline \multirow[t]{3}{*}{1} & Regression & 1468.051 & 2 & 734.026 & 91.441 & $.000^{\mathrm{b}}$ \\
\hline & Residual & 337.149 & 42 & 8.027 & & \\
\hline & Total & 1805.200 & 44 & & & \\
\hline \multicolumn{7}{|c|}{ a. Dependent Variable: Produktivitas kerja } \\
\hline \multicolumn{7}{|c|}{ b. Predictors: (Constant), Kepuasan kerja, Budaya Organisasi } \\
\hline
\end{tabular}

From the table above, the $\mathrm{F}$ value is 91.441 with a sig level of 0.000 . Because the sig value is less than 0.05 , the hypothesis which says there is an influence of Organizational Culture and Job Satisfaction on Work Productivity of Vocational High School 1 Bunga Mayang is accepted.

\section{CONCLUSION}

Results of data analysis Hypothesis 1 get the $t$ value is 12,705 with a sig level of 0,000 . Because the sig value is less than 0.05 , the hypothesis which says there is an influence of Organizational Culture on the work productivity of Vocational High School 1 Bunga Mayang is accepted. Simple correlation analysis between $\mathrm{X} 1$ and Y produces a correlation (r) of 0.889 . From the correlation table as described in the previous section, 0.889 are in the 0.800 to 1,000 , which means that the organizational culture variable on teacher work productivity has a very strong influence. The coefficient of determination is obtained from the square of the correlation coefficient, which is $(0.889) 2=0.790$. This shows that about $79.0 \%$ of the variation that occurs in variable $\mathrm{Y}$ can be explained by variations in variable $\mathrm{X} 1$.

Results of data analysis Hypothesis 2 get the $t$ value is 11,545 with a sig level of 0,000 . Because the sig value is less than 0.05 , the hypothesis which says there is an effect of Job Satisfaction on the work productivity of teachers of Vocational High School 1 Bunga Mayang is accepted. Simple correlation analysis between $\mathrm{X} 2$ and $\mathrm{Y}$ produces a correlation (r) of 0.870 . From the correlation table as described earlier where 0.870 is in 0.800 to 1,000 , which means that the variable Job Satisfaction on the work productivity of Vocational High School 1 Bunga Mayang High School teachers has a very strong influence. The coefficient of determination is obtained from the square of the correlation coefficient, which is $(0.870) 2=0.756$. This shows that about $75.6 \%$ of the variation that occurs in variable $Y$ can be explained by variations in variable $\mathrm{X} 2$.

The results of data analysis Hypothesis 3 get an $F$ value of 91.441 with a sig level of 0.000 . Because the sig value is less than 0.05 , the hypothesis which says there is an influence of Organizational Culture and Job Satisfaction together on the work productivity of Vocational High School 1 Bunga Mayang teachers is accepted. Multiple correlation analysis of X1 and X2 to $\mathrm{Y}$ produces a correlation $(\mathrm{r})$ of 0.902 . From the correlation table as explained in the previous, where 0.902 is above 0.800 , which means that the variables of Certification and Supervision of Principals with Teacher Performance have a very strong influence. The coefficient of determination is obtained from the square of the correlation coefficient, which is (0.902) $2=$ 0.813 . This shows that about $81.3 \%$ of the variations that occur in variable $\mathrm{Y}$ can be explained by variations in variables $\mathrm{X} 1$ and $\mathrm{X} 2$. Together, the influence of Organizational Culture and Job Satisfaction together on the work productivity of Vocational High School 1 Bunga Mayang Middle School teachers with a beta of 
0.560 and 0.361 means that the variables of organizational culture are more influential together. Descriptive and hypothesis testing can be concluded as follows: There is an influence of leadership style on the performance of school teachers 1 bunga mayang, there is an influence of work discipline on the performance of school teachers 1 Bunga Mayang.

For researchers to follow up further on the results of this study by developing independent variables that can increase work productivity of the 1 Bunga Mayang Vocational High School. This needs to be done because there are still other factors that have an influence on work productivity besides the Organizational Culture and Job Satisfaction because only $81.3 \%$ of work productivity is determined by Organizational Culture and Job Satisfaction, meaning $28.7 \%$ is determined by factors outside of Organizational Culture and Job Satisfaction such as compensation, job satisfaction and others.

\section{REFERENCES}

[1] Alpan. (2002). Pengaruh Budaya Organisasi dan Disiplin kerja tehadap Produktivitas kerja pegawai. MM-UTP.

[2] Anoraga, P., \& Suyati, S. (2009). Perilaku Keorganisasian. Dunia Pustaka Jaya: Jakarta.

[3] Mulyono. (2004). Manajemen Sumber Daya Manusia. Jakarta: Gramedia.

[4] Luthans, F. (2008). Organizational Behavior. Singapore: McGraw-Hill

[5] Simamora, Henry. 2015. Manajemen Sumber Daya Manusia. STIE YKPN. Yogyakarta

[6] Arikunto. S. (2010). Metode Penelitian dan Statistika: Dunia Pustaka Jaya. Jakarta

[7] Anizah., \& Maretta. W. F. (2020). Kepemimpinan Efektif Kepala Sekolah Dalam Mengembangkan profesionalisme Guru. Universitas PGRI Palembang Jurnal Intelektualita: Keislaman, Sosial dan Sains; Vol 9 No 1

[8] Hutapea, P., \& Thoha, N. (2008). Kompetensi Plus : Teori, Desain,. Kasus dan Penerapan untuk HR dan Organisasi yang Dinamis. Jakarta: PT Gramedia Pustaka.

[9] Bernardin, H.J. \& Russel, J.E.A. (2003). Human Resource Management an experiental approach. Singapore: Mc Graw-Hill, Inc.

[10] Boediono., \& Koster, W. (2004). Statistika dan Probabilitas. Jilid 3. Bandung: PT. Remaja Rosdakarya.

[11] Kurniawan, C. (2018). Pengaruh Motivasi Dan Kepemimpinan Terhadap Kinerja Pegawai Universitas PGRI Palembang. Universitas PGRI Palembang Jurnal Intelektualita: Keislaman, Sosial dan Sains; Vol 9 No 1 